\title{
Alternatives to antibiotics as growth promoters for use in swine production: a review
}

Philip A Thacker

\begin{abstract}
In the past two decades, an intensive amount of research has been focused on the development of alternatives to antibiotics to maintain swine health and performance. The most widely researched alternatives include probiotics, prebiotics, acidifiers, plant extracts and neutraceuticals such as copper and zinc. Since these additives have been more than adequately covered in previous reviews, the focus of this review will be on less traditional alternatives. The potential of antimicrobial peptides, clay minerals, egg yolk antibodies, essential oils, eucalyptus oil-medium chain fatty acids, rare earth elements and recombinant enzymes are discussed. Based on a thorough review of the literature, it is evident that a long and growing list of compounds exist which have been tested for their ability to replace antibiotics as feed additives in diets fed to swine. Unfortunately, the vast majority of these compounds produce inconsistent results and rarely equal antibiotics in their effectiveness. Therefore, it would appear that research is still needed in this area and that the perfect alternative to antibiotics does not yet exist.
\end{abstract}

Keywords: Antimicrobial peptides, Clay minerals, Egg yolk antibodies, Essential oils, Eucalyptus oil-medium chain fatty acids, Rare earth elements, Recombinant enzymes

\section{Background}

Antibiotics have played a major role in the growth and development of the swine industry for more than 50 years. Their efficiency in increasing growth rate, improving feed utilization and reducing mortality from clinical disease is well documented [1]. However, consumers are becoming increasingly concerned about drug residues in meat products [2]. In addition, it has been suggested that the continuous use of antibiotics may contribute to a reservoir of drug-resistant bacteria which may be capable of transferring their resistance to pathogenic bacteria in both animals and humans [3]. As a result, many countries have banned or are banning the inclusion of antibiotics in swine diets as a routine means of growth promotion.

In the past two decades, an intensive amount of research has been focused on the development of alternatives to antibiotics to maintain swine health and performance and many excellent reviews have already been published on this subject. The most widely researched alternatives include probiotics [4-6], prebiotics [4,7],

Correspondence: phil.thacker@usask.ca

Department of Animal and Poultry Science, University of Saskatchewan, 51 Campus Drive, Saskatoon, Saskatchewan S7N 5A8, Canada enzymes [8-10], acidifiers [11-14], plant extracts $[4,15$, $16]$ and neutraceuticals such as copper and zinc $[17,18]$. Since these additives have been more than adequately covered, the focus of this review will be on less traditional alternatives.

\section{Antimicrobial peptides}

Antimicrobial peptides, as the name implies, are peptides with antimicrobial properties. They have been isolated and characterized from virtually all living organisms ranging from prokaryotes to humans [19]. They are important components of the host's defense system and are effector molecules of innate immunity with direct antimicrobial and mediator function [20]. Most antimicrobial peptides contain between 30 and 60 amino acids and are polar molecules with spatically separated hydrophobic and charged regions. Antimicrobial peptides have been identified that have activity against Gram-positive and Gram-negative bacteria as well as against fungi and enveloped viruses [20].

More than 700 antimicrobial peptides are known to exist [20]. Bioscreening, cloning strategies and computer-based database searches have been used to identify antimicrobial peptides which have potential to be used 
as alternatives to antibiotics [20]. Once identified, it is possible to chemically synthesize most antimicrobial peptides but the high cost of this process precludes the production of peptides through this method for use as feed additives. However, several research groups have developed recombinant systems for expression of antimicrobial peptides.

Antimicrobial proteins produced by bacteria are called bacteriosins. These proteins have several characteristics that make them desirable alternatives to conventional antibiotics for use in swine production. Most importantly, bacteria have difficulty in developing resistance against these peptides [21]. Peptides have a narrow spectrum of activity so they can be used to target specific pathogenic bacteria without affecting the normal native flora. There is almost no risk of residues in meat because they are proteins and therefore will not be absorbed as an intact molecule. In addition, antimicrobial peptides can tolerate a wide range of $\mathrm{pH}$ and temperatures [22].

The antimicrobial activity of peptides is based on several mechanisms. In most cases, interactions between the peptide and the surface membranes of the target bacteria are thought to be responsible for their killing activity [20]. These interactions are proposed to lead to a loss of membrane function including breakdown of membrane potential, leakage of metabolites and ions, and alteration of membrane permeability [19]. These alterations in the bacterial membrane can result in cell lysis or, alternatively, can lead to the formation of transient pores and the transport of peptides inside the cell bringing them into contact with intracellular targets. Other mechanisms of antimicrobial activity include the inhibition of protein and RNA synthesis [20].

To date, the most prevalent use of antimicrobial peptides has been in the preservation of foods and few studies have been conducted using antimicrobial peptides with swine. One promising research area has been in the use of the antimicrobial peptide colicin. Colicins are a class of bacteriocin produced by and effective against Escherichia coli (E. coli) and closely related species. They have been shown to be effective against many pathogenic E. coli strains including those responsible for postweaning diarrhea and edema disease in pigs [23,24].

A chemically synthesized antimicrobial peptide A3 has been shown to have beneficial effects on weanling pig performance, nutrient digestibility, intestinal morphology as well as intestinal and fecal microflora [25,26]. In addition, an antimicrobial peptide isolated from the intestine of the Rongchang pig improved performance but had no effect on diarrhea incidence in weanling pigs [27]. However, the antimicrobial peptide appeared to act synergistically with zinc as the two additives in combination were superior to either additive fed separately.
The results of a feeding trial in which the antimicrobial peptide cecropin, originally isolated from the silkworm Hyalophora cecropia, was fed to weanling pigs challenged with enterotoxigenic E. coli K88 are shown in Table 1. Use of the antimicrobial peptide cecropin resulted in similar performance to pigs fed a combination of antibiotics [21]. The improvement in performance appeared to be related to improvements in nutrient digestibility and intestinal morphology. Cecropin treatment decreased total aerobes while increasing total anaerobes in the ileum compared with the control (Table 2). Cecropin also increased the numbers of beneficial lactobacillus in the cecum. Cecropin increased serum IgA and IgG and the inflammatory cytokines interleukin-1 $\beta$ and interleukin 6 indicating that cecropin activates both systemic and local immune systems in response to $E$. coli challenge.

Although there is little research on these compounds, the use of antimicrobial peptides appears to have considerable potential as a replacement for antibiotics in rations fed to swine. A commercial entity (Beijing Longkefangzhou Biological Engineering Technology Company, Beijing, China) has started to market cecropin for use in swine rations in China.

\section{Clay minerals}

Clay minerals are formed by a net of stratified tetrahedral and octahedral layers [2]. They contain molecules of silicon, aluminum and oxygen. The natural extracted clays (bentonites, zeolite, kaolin) are a mixture of various clays differing in chemical composition. The best known are montmorillonite, smectite, illite, kaolinite, biotic and clinoptilolite [2].

Clays added to the diet can bind and immobilize toxic materials in the gastrointestinal tract of animals and thereby reduce their biological availability and toxicity [2]. Clay minerals can bind aflatoxins, plant metabolites, heavy metals, and toxins. The extent of adsorption is determined by the chemistry of the clay minerals, exchangeable ions, surface properties and the fine structure of the clay particles [2]. An important role is played by $\mathrm{pH}$, dosage and exposure time. As a result of their binding properties, clays have been widely used in swine diets to improve pig performance when diets containing mycotoxins are fed [28,29].

Clays have also been shown to prevent diarrhea in weaned pigs [2,30,31]. Based on this fact, several research groups have attempted to determine whether or not the inclusion of various clays in swine diets can improve pig performance. The results have been inconclusive with some trials demonstrating positive results particularly for younger pigs [30], but the vast majority of the experiments have failed to show improvements 
Table 1 Effects of antibiotics or an antimicrobial peptide cecropin on the performance of four week old weaned pigs after challenge with $E$. coli as well as nutrient digestibility before challenge

\begin{tabular}{|c|c|c|c|c|c|}
\hline Items & Control & Antibiotics $^{1}$ & Cecropin & SEM & $P$-value \\
\hline \multicolumn{6}{|l|}{ Performance (day 13-19) } \\
\hline Weight gain, g/d & $312^{\mathrm{a}}$ & $367^{\mathrm{b}}$ & $358^{\mathrm{b}}$ & 6.4 & $<0.01$ \\
\hline Feed intake, g/d & 566 & 597 & 592 & 9.8 & 0.08 \\
\hline Feed efficiency & $0.55^{\mathrm{a}}$ & $0.62^{\mathrm{b}}$ & $0.61^{\mathrm{b}}$ & 0.01 & $<0.01$ \\
\hline Diarrhea incidence, \% & 37.50 & 17.86 & 19.64 & & \\
\hline \multicolumn{6}{|l|}{ Nutrient digestibility } \\
\hline Nitrogen retention, $\mathrm{g} / \mathrm{d}$ & $10.1^{\mathrm{a}}$ & $11.5^{\mathrm{b}}$ & $10.7^{\mathrm{ab}}$ & 0.38 & 0.04 \\
\hline Nitrogen digestibility, \% & 73.2 & 76.9 & 75.0 & 1.20 & 0.17 \\
\hline Energy retention, $\mathrm{MJ} / \mathrm{kg} / \mathrm{d}$ ) & $2.5^{\mathrm{a}}$ & $3.0^{\mathrm{b}}$ & $2.8^{\mathrm{ab}}$ & 0.13 & 0.04 \\
\hline Energy digestibility, \% & 84.6 & 88.2 & 86.4 & 1.71 & 0.14 \\
\hline
\end{tabular}

Wu et al. [21].

'Kitasamycin and colistin sulfate.

a,bWithin row, means followed by same or no letter do not differ $(P>0.05)$.

Table 2 Effects of antibiotics or the antimicrobial peptide cecropin on intestinal morphology and intestinal microflora of four week old weaned pigs after challenge with $E$. coli

\begin{tabular}{|c|c|c|c|c|c|}
\hline Items & Control & Antibiotic $^{1}$ & Cecropin & SEM & $P$-value \\
\hline \multicolumn{6}{|l|}{ Intestinal Morphology } \\
\hline \multicolumn{6}{|l|}{ Duodenum } \\
\hline Villus height, $\mu \mathrm{m}$ & 418 & 439 & 431 & 10.7 & 0.53 \\
\hline Crypt depth, $\mu \mathrm{m}$ & 233 & 227 & 232 & 5.3 & 0.41 \\
\hline Villus height to crypt depth ratio & 1.83 & 1.96 & 1.89 & 0.24 & 0.18 \\
\hline \multicolumn{6}{|l|}{ Jejunum } \\
\hline Villus height, $\mu \mathrm{m}$ & 401 & 448 & 420 & 18.4 & 0.37 \\
\hline Crypt depth, $\mu \mathrm{m}$ & $212^{b}$ & $233^{\mathrm{a}}$ & $220^{b}$ & 6.8 & 0.04 \\
\hline Villus height to crypt depth ratio & $1.89^{b}$ & $1.97^{\mathrm{a}}$ & $1.91^{\mathrm{ab}}$ & 0.01 & 0.03 \\
\hline \multicolumn{6}{|l|}{ Ileum } \\
\hline Villus height, $\mu \mathrm{m}$ & $357^{b}$ & $396^{\mathrm{a}}$ & $384^{\mathrm{a}}$ & 12.4 & 0.04 \\
\hline Crypt depth, $\mu \mathrm{m}$ & 211 & 217 & 213 & 5.6 & 0.37 \\
\hline Villus height to crypt depth ratio & $1.74^{\mathrm{b}}$ & $1.85^{\mathrm{a}}$ & $1.82^{\mathrm{ab}}$ & 0.04 & 0.04 \\
\hline \multicolumn{6}{|c|}{ Intestinal Microflora ( $\log _{10} \mathrm{CFU} / \mathrm{g}$ of digesta) } \\
\hline \multicolumn{6}{|l|}{ lleum } \\
\hline E. coli & 4.37 & 4.14 & 4.25 & 0.18 & 0.85 \\
\hline Lactobacillus & 9.38 & 10.00 & 9.62 & 0.20 & 0.42 \\
\hline Total aerobes & $6.69^{\mathrm{a}}$ & $6.60^{\mathrm{ab}}$ & $6.43^{b}$ & 0.08 & 0.04 \\
\hline Total anaerobes & $9.36^{\mathrm{b}}$ & $9.87^{\mathrm{ab}}$ & $10.12^{\mathrm{a}}$ & 0.23 & 0.03 \\
\hline \multicolumn{6}{|l|}{ Cecum } \\
\hline E. coli & $3.37^{\mathrm{a}}$ & $3.09^{b}$ & $3.22^{\mathrm{ab}}$ & 0.12 & 0.04 \\
\hline Lactobacillus & $8.89^{b}$ & $9.47^{\mathrm{a}}$ & $9.23^{\mathrm{a}}$ & 0.14 & 0.03 \\
\hline Total aerobes & 3.88 & 3.77 & 3.49 & 0.44 & 0.63 \\
\hline Total anaerobes & 8.79 & 9.37 & 9.26 & 0.28 & 0.38 \\
\hline
\end{tabular}

Wu et al. [21].

${ }^{1}$ Kitasamycin and colistin sulfate.

a,b Within row, means followed by same or no letter do not differ $(P>0.05)$. 
[32-35]. It would appear that clay minerals are not viable alternatives to antibiotics as growth promoters.

\section{Egg yolk antibodies}

One technique that appears to have considerable potential as an alternative to antibiotics for growth promotion in the presence of disease causing organisms is the use of egg yolk antibodies generally referred to as IgY [36]. In order to produce these antibodies, laying hens are injected with organisms that cause specific diseases in swine. The injection of these antigens induces an immune response in the hen which results in the production of antibodies. These antibodies are typically deposited in the egg yolk. Booster immunizations are given to ensure continued transfer of antibodies from the hen to the egg yolk. These antibodies are then extracted from the egg yolk and processed. Antibodies can be administered in the feed in several forms including whole egg powder, whole yolk powder, water-soluble fraction powder or purified IgY [37]. Details concerning IgY production including choice of adjuvant, route of immunization, dose, immunization frequency and techniques for IgY extraction from the yolk have been reviewed by Chalghoumi et al. [37] and Kovacs-Nolan and Mine [38].

Compared with the use of mammals such as rabbits or sheep for antibody production, the immunization of chickens for antibody production is an attractive approach. Chicken housing is inexpensive, egg collection is non-invasive, the IgY antibodies are concentrated in egg yolk and isolation is fast and simple. In addition, chicken immunnoglobin does not react with mammalian IgG or IgM and also it does not activate mammalian complement factors [38]. Finally, the use of IgY elicits no undesirable side effects, disease resistance or toxic residues [36].

IgY antibodies have been tested against a number of enteric pathogens in swine including E. coli, Salmonella and Rotavirus with varying degrees of success [39-43]. Table 3 shows the results of an experiment where the performance of pigs fed egg yolk antibodies was compared with that of pigs fed diets supplemented with zinc oxide, fumaric acid or antibiotics. All four feed additives successfully increased pig performance compared with unsupplemented pigs with significant reductions observed in scour score and piglet mortality. In this experiment, egg yolk antibody was equal to antibiotics in enhancing pig performance.

Unfortunately, there are several reports where egg yolk antibody failed to improve pig performance $[42,44]$. The most likely explanation for the failure of egg yolk antibody to improve performance is that the antibody failed to survive passage through the gastrointestinal tract [45]. It appears that the IgY molecule is less stable than the IgG molecule due to its higher molecular weight, lower percentage of $\beta$-sheet structure and reduced flexibility [45]. It has been reported that the activity of IgY was decreased at $\mathrm{pH} 3.5$ or lower and almost completely lost activity with irreversible change at $\mathrm{pH} 3$ [37]. In addition, IgY is fairly sensitive to pepsin digestion [45]. Therefore, a recent avenue of research has been to use microencapsulation techniques to protect IgY from gastric inactivation $[46,47]$.

Table 4 shows the results of an experiment where chitosan-alginate microcapsules were used for oral delivery of egg yolk immunoglobulin in weaned pigs challenged with enterotoxigenic E. coli C83903 [46]. The percentage of pigs with diarrhea $24 \mathrm{~h}$ after treatment and the diarrhea score were improved in pigs receiving encapsulated IgY compared with non-encapsulated IgY. In addition, weight gain over the three day period was significantly higher in pigs receiving encapsulated IgY compared with non-encapsulated IgY. Both encapsulated and non-encapsulated IgY treatments were numerically superior to an aureomycin treated group.

The mechanism through which IgY counteracts pathogen activity has not been determined. However, several mechanisms were proposed by $\mathrm{Xu}$ et al. [36] including agglutination of bacteria, inhibition of adhesion, opsoni-

Table 3 Effect of egg yolk antibody, zinc oxide, fumaric acid and antibiotic on the performance and intestinal morphology of 10 to 24 day old pigs fed diets based on pea protein concentrate

\begin{tabular}{|c|c|c|c|c|c|c|}
\hline Items & Control & Egg yolk antibody & Zinc oxide & Fumaric acid & Carbadox & SEM \\
\hline Weight gain, g/d & 100.9 & 151.2 & 158.9 & 155.4 & 152.6 & 16.6 \\
\hline Feed intake, $\mathrm{g} / \mathrm{d}$ & 141.0 & 208.1 & 214.7 & 211.6 & 222.4 & 15.3 \\
\hline Feed conversion & 1.39 & 1.38 & 1.35 & 1.36 & 1.45 & 0.04 \\
\hline Scour score & 2.7 & 1.3 & 1.4 & 1.3 & 1.1 & - \\
\hline Mortality, \% & 40.0 & 6.6 & 13.3 & 6.6 & 13.3 & - \\
\hline Villus height, m & 355 & 564 & 488 & 573 & 570 & 20.0 \\
\hline Crypt depth, m & 204 & 183 & 190 & 207 & 204 & 10.1 \\
\hline Villous height:crypt depth & 1.7 & 3.1 & 2.6 & 2.8 & 2.8 & 0.11 \\
\hline
\end{tabular}

Owusu-Asiedu et al. [41]. 
Table 4 Effect of encapuslation of IgY on performance and the incidence of diarrhea in pigs challenged with $E$. coli

\begin{tabular}{|c|c|c|c|c|c|c|}
\hline \multirow[b]{2}{*}{ Items } & \multicolumn{4}{|c|}{$\begin{array}{l}\text { Percentage of pigs with diarrhea after } \\
\text { specific times (Fecal score in brackets) }\end{array}$} & \multirow[b]{2}{*}{ Weight gain $(g / d)$} & \multirow[b]{2}{*}{ Recovery rate $(\%)$} \\
\hline & $9 \mathrm{~h}$ & $24 \mathrm{~h}$ & $48 \mathrm{~h}$ & $72 \mathrm{~h}$ & & \\
\hline Negative control, unchallenged & $0 \%(0.5)$ & $0 \%(0.0)$ & $0 \%(0.4)$ & $0 \%(0.0)$ & $116.6^{\mathrm{a}}$ & - \\
\hline Positive control & $75 \%(2.5)$ & $75 \%(2.5)$ & $75 \%(2.0)$ & $75 \%(2.0)$ & $13.5^{\mathrm{d}}$ & $0 \%$ \\
\hline Non-encapsulated IgY & $100 \%(2.0)$ & $75 \%(1.3)$ & $25 \%(1.0)$ & $0 \%(0.0)$ & $78.1^{\mathrm{b}}$ & $100 \%$ \\
\hline Microencapsulated $\lg Y$ & $75 \%(2.0)$ & $0 \%(0.0)$ & $0 \%(0.0)$ & $0 \%(0.0)$ & $110.4^{\mathrm{a}}$ & $100 \%$ \\
\hline Aureomycin & $100 \%(2.0)$ & $50 \%(2.0)$ & $75 \%(1.5)$ & $50 \%(1.5)$ & $54.1^{c}$ & $50 \%$ \\
\hline
\end{tabular}

Li et al. [46].

${ }^{1}$ Fecal score is the mean fecal consistency score where $0=$ normal, $1=$ soft feces, $2=$ mild diarrhea, $3=$ severe diarrhea

$\mathrm{a}, \mathrm{b}, \mathrm{c}, \mathrm{d}$ Within column, means followed by same or no letter do not differ $(P>0.05)$.

zation followed by phagocytosis and toxin neutralization. Further research is necessary to determine the exact mechanism for the growth promoting activity of IgY.

\section{Essential oils}

Essential oils are aromatic oily liquids obtained from plant material and usually have the characteristic odor or flavor of the plant from which they are obtained [48]. They are typically mixtures of secondary plant metabolites and may contain phenolic compounds (i.e. thymol, carvacrol and eugenol), terpenes (i.e. citric and pinapple extracts), alkaloids (capsaicine), lectins, aldehydes (i.e. cinnamaldehyde), polypeptides or polyacetylenes [49]. They can be extracted from plants with organic solvents or steam distillation [49]. An estimated 3000 essential oils are known to exist but cinnamaldehyde, carvacrol, eugenol and thymol have received the most interest for use in swine production.

Interest in the use of essential oils as a potential replacement for antibiotics in swine rations has been generated as a result of in vitro studies showing that essential oils have antimicrobial activity against microflora commonly present in the pig gut [50]. The exact mode of action of essential oils has not been established but the activity may be related to changes in lipid solubility at the surface of the bacteria [48]. The hydrophobic constituents of essential oils allow them to disintegrate the outer membrane of E. coli and Salmonella and thus inactivate these pathogens [48]. This would result in a shift in the microbial ecology in favor of lactic acid producing bacteria and reducing the number of pathogenic bacteria [50]. Essential oils containing phenolic compounds tend to have greater antimicrobial activity than oils containing other compounds [51].

Based on the fact that essential oils appear to control pathogenic bacteria, several research groups have attempted to determine whether or not the inclusion of essential oils in swine diets can improve pig performance [52]. The results have been inconclusive with some trials demonstrating positive results [53-55] while others have reported no beneficial effects [56,57]. The most compelling evidence for including essential oils in diets fed to swine can be obtained from the results of $\mathrm{Li}$ et al. [55]. This trial compared the performance of pigs fed an unsupplemented control diet with that of pigs fed a diet supplemented with antibiotics or a combination of thymol and cinnamaldehyde (Table 5). Weight gain, feed conversion and fecal consistency of pigs fed essential oils was essentially equal to that of pigs fed antibiotics. The improved performance appeared to be mediated by improvements in dry matter and protein digestibility arising from improvements in intestinal morphology. In addition, total antioxidant capacity and levels of the cytokines interleukin- 6 and tumor necrosis factor- $\alpha$ were altered by inclusion of essential oils (Table 6).

The reason for the variability in results when essential oils are fed is likely due to differences in the type of essential oils used and the dose provided [55]. As noted previously, oils containing phenolic compounds tend to have greater antimicrobial activity than those based on other compounds. In addition, if the dose used is too high, the strong smell can reduce feed intake and thereby limit pig performance [48]. Another important consideration is the stability of essential oils during pelleting. Maenner et al. [54] reported considerable loss

Table 5 Effect of essential oils on weanling pig performance, nutrient digestibility and fecal consistency

\begin{tabular}{lllll}
\hline Items & Control & Antibiotic $^{1}$ & Essential oil & SEM \\
\hline Performance & & & & \\
Weight gain, g/d & $442^{\mathrm{a}}$ & $505^{\mathrm{b}}$ & $493^{\mathrm{b}}$ & 15 \\
Feed intake, g/d & 783 & 846 & 789 & 24 \\
Feed conversion & 1.79 & 1.67 & 1.62 & 0.06 \\
Fecal consistency & $1.53^{\mathrm{a}}$ & $1.22^{\mathrm{b}}$ & $1.30^{\mathrm{b}}$ & 0.06 \\
Nutrient digestibility & & & \\
Dry matter & $84.33^{\mathrm{a}}$ & $87.03^{\mathrm{b}}$ & $86.92^{\mathrm{b}}$ & 0.65 \\
Crude protein & $76.51^{\mathrm{a}}$ & $83.53^{\mathrm{b}}$ & $81.34^{\mathrm{b}}$ & 1.25 \\
\hline
\end{tabular}

Li et al. [55].

${ }^{1}$ Chlortetracycline, colistin sulfate and kitasamycin.

${ }^{a, b}$ Within row, means followed by same or no letter do not differ $(P>0.05)$. 
Table 6 Effect of essential oils on intestinal morphology, antioxidant capacity, and cytokine levels in weanling pigs

\begin{tabular}{|c|c|c|c|c|}
\hline Items & Control & Antibiotic $^{1}$ & Essential oil & SEM \\
\hline Villus height, $\mu \mathrm{m}$ & 466 & 509 & 535 & 24 \\
\hline Crypt depth, $\mu \mathrm{m}$ & 164 & 156 & 162 & 8 \\
\hline Villus height:crypt depth & $2.96^{\mathrm{a}}$ & $3.41^{\mathrm{b}}$ & $3.38^{\mathrm{b}}$ & 0.09 \\
\hline Total antioxidant capacity, $\mathrm{U} / \mathrm{mL}$ & $10.46^{\mathrm{a}}$ & $11.97^{\mathrm{ab}}$ & $12.37^{\mathrm{b}}$ & 0.52 \\
\hline Interleukin-6, ng/L & $44.21^{\mathrm{a}}$ & $40.39^{a}$ & $27.40^{b}$ & 2.76 \\
\hline Tumor necrosis factor-a, ng/L & $208^{\mathrm{a}}$ & $237^{\mathrm{ab}}$ & $260^{b}$ & 13 \\
\hline
\end{tabular}

Li et al. [55].

${ }^{1}$ Chlortetracycline, colistin sulfate and kitasamycin.

a,b Within row, means followed by same or no letter do not differ $(P>0.05)$.

of activity of essential oils when a pelleting temperature of $58^{\circ} \mathrm{C}$ was applied.

\section{Eucalyptus oil-medium chain fatty acids}

Eucalyptus oil is obtained from the leaves of the eucalyptus, a tree which belongs to the plant family Myrtaceae and is cultivated worldwide. In humans, eucalyptus oil has been shown to have antibacterial effects on pathogenic bacteria in the respiratory tract [58]. Eucalyptus oil has also been shown to stimulate the immune system by affecting the phagocytic ability of monocyte-derived macrophages [59]. In poultry, dietary inclusion of eucalyptus has been shown to improve production performance and stimulate the immunity of commercial laying hens [60].

Medium-chain fatty acids have been suggested as an alternative feed additive to antibiotics for piglets [61-63]. Medium chain fatty acids have been shown to have antimicrobial activity against Salmonella [64] and E. coli [61]. Hong et al. [63] reported that feeding a blend of caprylic and caproic acids improved performance and nutrient digestibility in 3 and 4 week old weaned pigs during the first two weeks following weaning.

Micro-encapsulation of medium chain fatty acids is a process in which medium chain fatty acids are nanomicronized to extremely small particles and then encapsulated. Han et al. [65] tested a product where eucalyptus extract was mixed with caprylic and carpric acids and encapsulated with palm oil in comparison with antibiotics or zinc oxide (Table 7). The performance of pigs fed the eucalyptus-medium chain fatty acid blend was essentially equal to that of antibiotics or zinc oxide.
The performance enhancing effects of the blend appeared to be mediated through improvements in nutrient digestibility (Table 8). The process used to produce the microencapsualted eucalyptus-medium chain fatty acid blend has been patented by the Korean Intellectual Property Office under patent number 10-2009-0025329.

\section{Rare earth elements}

Rare earth elements comprise the elements scandium, yttrium, lanthanum and the 14 chemical elements following lanthanum in the periodic table called lanthanoids [66]. The application of rare earth elements as feed additives for livestock has been practiced in China for decades [66]. There are many articles in the Chinese literature concerning the performance enhancing effects of rare earth elements for swine $[67,68]$ and many more have been reviewed by Rambeck and Wehr [69] and Redling [66]. In the Chinese literature, body weight gain was shown to be improved by 5 to $23 \%$ and feed conversion between 4 and 19\% under the influence of rare earth elements.

Research concerning the effect of rare earth elements on swine performance have been published in the Western literature since about the year 2000 with some reports indicating significant improvements in pig performance [70,71] while others have observed no change [72]. Table 9 shows the results of a recent trial in which the performance of weaned pigs fed a lanthanum-yeast mixture was similar to that of pigs fed diets supplemented with antibiotics or zinc oxide [73].

The products commonly used as feed additives for swine are typically mixtures of rare earth elements

Table 7 Effects of antibiotics, zinc oxide, and eucalyptus-medium chain fatty acids (MCFA) on nursery pig performance

\begin{tabular}{|c|c|c|c|c|c|c|c|}
\hline Items & Control & Antibiotics $^{1}$ & $\mathrm{ZnO}(1,500 \mathrm{ppm})$ & $\mathrm{ZnO}(2,500 \mathrm{ppm})$ & Eucalyptus-MCFA & SEM & $P$ \\
\hline Weight gain, g/d & $243^{a}$ & $315^{\mathrm{b}}$ & $298^{\mathrm{b}}$ & $308^{\mathrm{b}}$ & $310^{\mathrm{b}}$ & 13.6 & $<0.01$ \\
\hline Feed intake, $\mathrm{g} / \mathrm{d}$ & $361^{a}$ & $431^{b}$ & $426^{b}$ & $429^{b}$ & $448^{\mathrm{b}}$ & 18.1 & $<0.01$ \\
\hline Feed conversion & 1.53 & 1.41 & 1.44 & 1.41 & 1.46 & 0.05 & 0.35 \\
\hline
\end{tabular}

Han et al. [65].

${ }^{1}$ Tiamulin and lincomycin.

a,b Within row, means followed by same or no letter do not differ $(P>0.05)$. 
Table 8 Effects of antibiotics, zinc oxide, and eucalyptus-medium chain fatty acids (MCFA) on nutrient digestibility for weaned pigs

\begin{tabular}{|c|c|c|c|c|c|c|}
\hline Items & Antibiotics $^{1}$ & $\mathrm{ZnO}(1,500 \mathrm{ppm})$ & $\mathrm{ZnO}(2,500 \mathrm{ppm})$ & Eucalyptus-MCFA & SEM & $P$ \\
\hline Dry matter & $91.74^{\mathrm{a}}$ & $90.58^{\mathrm{b}}$ & $90.44^{\mathrm{b}}$ & $92.17^{\mathrm{a}}$ & 0.26 & $<0.01$ \\
\hline Crude protein & $74.18^{a}$ & $72.01^{a}$ & $71.23^{\mathrm{a}}$ & $78.93^{b}$ & 1.13 & $<0.01$ \\
\hline Calcium & $56.31^{a}$ & $48.26^{b}$ & $46.75^{b}$ & $65.93^{c}$ & 1.56 & $<0.01$ \\
\hline Phosphorus & $54.48^{\mathrm{a}}$ & $38.25^{b}$ & $42.77^{b}$ & $66.10^{b}$ & 2.01 & $<0.01$ \\
\hline Energy & $82.92^{\mathrm{a}}$ & $81.60^{b}$ & $81.00^{b}$ & $86.00^{c}$ & 0.61 & $<0.01$ \\
\hline Lysine & $79.13^{a}$ & $80.25^{b}$ & $78.25^{\mathrm{a}}$ & $83.80^{b}$ & 0.88 & $<0.01$ \\
\hline Methionine & $83.94^{\mathrm{a}}$ & $80.95^{b}$ & $80.78^{b}$ & $84.23^{a}$ & 0.63 & $<0.01$ \\
\hline Threonine & $73.56^{b}$ & $73.57^{b}$ & $73.43^{b}$ & $79.40^{\mathrm{a}}$ & 1.40 & 0.02 \\
\hline
\end{tabular}

Han et al. [65].

'Tiamulin and lincomycin.

a,b Within row, means followed by same or no letter do not differ $(P>0.05)$

mainly containing lanthanum, cerium and praseodymium [73]. Both inorganic and organic rare earth compounds have been used as feed additives but it is believed that best results are obtained with organic compounds [66].

Several mechanisms have been proposed for the growth promoting effects of rare earth elements. It has been suggested that rare earth elements may promote growth by influencing the development of undesirable bacterial species within the gastrointestinal tract. For example, lanthanum has been shown to bind to the surface of bacteria [69]. This reduces the surface charge and retards electrophoretic migration. When the surface charge is completely neutralized, flocculation occurs. In addition, bacterial respiration has been shown to be strongly inhibited by lanthanides [69].

Another explanation for the growth promoting effects of rare earth elements is due to improvements in nutrient digestibility and availability as was observed by Han and Thacker [73; Table 10]. It has been suggested that rare earth elements may influence the permeability of the intestines thereby enhancing the absorption of different nutrients [66]. Enhanced secretion of digestive fluids and increased gastrointestinal motility have also been proposed as explanations for the enhanced digestibility of nutrients following dietary inclusion of rare earth elements [66].

Rare earth elements have several properties that make them attractive alternatives to antibiotics. Generally, absorption of orally applied rare earths is low with more than $95 \%$ being recovered in the feces of animals [66]. As a result, the chances of residues being present in meat are low with studies reporting no higher levels of rare earth elements in the muscle tissue of supplemented animals than those fed commercial diets [66]. In addition, there have been no reports of the development of bacterial resistance in treated animals [66].

\section{Recombinant enzymes}

Enzymes are biologically active proteins that break specific chemical bonds to release nutrients for further digestion and absorption. They accelerate chemical reactions in the body which would otherwise proceed very slowly or not at all [74]. Enzymes used in the feed industry are commonly produced by bacteria (i.e. Bacillus subtilis), fungus (i.e. Trichoderma reesei, Aspergillus niger) or yeast (Saccharomyces cerevisiae).

The supplementation of swine diets with exogenous enzymes to enhance performance is not a new concept and research articles in this field date back to the 1950's [10]. The most common reasons for enzyme supplementation include degrading feed components resistant to endogenous enzymes (i.e. $\beta$-glucanase, xylanase, mannanase, pectinase and galactosidase), inactivating antinutritional factors (i.e. phytase) and supplementing endogenous enzymes that may be present in insufficient amounts (i.e. proteases, lipases and amylases). This

Table 9 Effects of zinc oxide, antibiotic, or lanthanum-yeast on the performance of weanling pigs (day 0 to 28)

\begin{tabular}{|c|c|c|c|c|c|c|c|}
\hline Items & Control & Antibiotic $^{1}$ & Zinc $(1,500 \mathrm{ppm})$ & Zinc $(2,500 \mathrm{ppm})$ & Lanthanum-yeast & SEM & $P$ Values \\
\hline Weight gain, g/d & $302^{b}$ & $353^{a}$ & $352^{a}$ & $369^{a}$ & $359^{a}$ & 14.0 & 0.02 \\
\hline Feed intake, $\mathrm{g} / \mathrm{d}$ & $467^{b}$ & $518^{\mathrm{ab}}$ & $530^{\mathrm{ab}}$ & $558^{\mathrm{a}}$ & $501^{a b}$ & 22.6 & 0.10 \\
\hline Feed conversion & $1.55^{\mathrm{a}}$ & $1.47^{\mathrm{ab}}$ & $1.50^{\mathrm{ab}}$ & $1.52^{\mathrm{ab}}$ & $1.41^{\mathrm{b}}$ & 0.04 & 0.31 \\
\hline
\end{tabular}

Han and Thacker [73].

'Tiamulin and chlortetraccycline.

a,b Within row, means followed by same or no letter do not differ $(P>0.05)$. 
Table 10 Effects of antibiotics, zinc oxide or lanthanum-yeast on nutrient digestibility

\begin{tabular}{|c|c|c|c|c|c|c|}
\hline Items & Antibiotics $^{1}$ & Zinc(1,500 ppm) & Zinc $(2,500 \mathrm{ppm})$ & Lanthanum-yeast & SEM & $P$-value \\
\hline Dry matter & $95.19^{a}$ & $93.83^{b}$ & $93.98^{b}$ & $95.46^{\mathrm{a}}$ & 0.30 & $<0.01$ \\
\hline Crude protein & $74.51^{\mathrm{ab}}$ & $71.55^{\mathrm{b}}$ & $72.33^{b}$ & $78.34^{\mathrm{a}}$ & 1.38 & 0.01 \\
\hline Calcium & $56.59^{b}$ & $46.98^{c}$ & $48.50^{c}$ & $65.10^{\mathrm{a}}$ & 1.69 & $<0.01$ \\
\hline Phosphorus & $54.87^{b}$ & $43.07^{c}$ & $38.52^{c}$ & $66.11^{\mathrm{a}}$ & 2.09 & $<0.01$ \\
\hline Energy & $83.51^{b}$ & $81.42^{\mathrm{b}}$ & $81.33^{b}$ & $86.89^{a}$ & 0.80 & $<0.01$ \\
\hline Lysine & $81.45^{b}$ & $79.42^{b}$ & $80.32^{\mathrm{b}}$ & $85.15^{\mathrm{a}}$ & 0.95 & $<0.01$ \\
\hline Methionine & $83.49^{b}$ & $83.67^{b}$ & $86.76^{\mathrm{a}}$ & $87.32^{a}$ & 0.79 & $<0.01$ \\
\hline Phenylalanine & $74.21^{b}$ & $73.75^{b}$ & $75.41^{\mathrm{ab}}$ & $78.96^{\mathrm{a}}$ & 1.32 & 0.05 \\
\hline Threonine & $76.19^{b}$ & $75.13^{b}$ & $75.28^{b}$ & $81.19^{a}$ & 1.58 & 0.04 \\
\hline
\end{tabular}

Han and Thacker [73].

${ }^{1}$ Tiamulin and chlortetraccycline.

$a, b, c$ Within row, means followed by same or no letter do not differ $(P>0.05)$.

review will focus on the use of enzymes to degrade feed components resistant to endogenous enzymes.

The cell walls of cereal grains, legumes and oilseed meals are comprised of complex carbohydrates commonly referred to as non-starch polysaccharides [75]. Non-starch polysaccharides consist of a wide range of polymers which include cellulose, hemicellulose, pectins, $\beta$-glucans, $\alpha$-galctosides (raffinose, stachnyose and verbascose) and xylans [8]. These non-starch polysaccharides reduce the nutritional value of feed ingredients in a number of ways [74]. Firstly, they are indigestible by mammalian enzymes and therefore dilute the energy and nutrient content of the feed. Secondly, non-starch polysaccharides exhibit a so called "cage effect" whereby normally highly digestible nutrients such as starch, fat and protein are entrapped in a coating of non-starch polysaccharides preventing access of the endogenous enzymes to these substrates [76]. In addition, certain nonstarch polysaccharides may increase intestinal viscosity. It has also been suggested that non-starch polysaccharides allow microbial populations to assimilate a greater proportion of the nutrients contained in the feed into their own system thereby reducing the availability of these nutrients to the host [8].

Carbohydrases include all enzymes that catalyze a reduction in the molecular weight of polymeric carbohydrate but more than $80 \%$ of the global carbohydrase market is accounted for by xylanase and $\beta$-glucanase [10]. Other commercially available carbohydrases include $\alpha$-amylase, $\beta$-mannanase, $\alpha$-galactosidase and pectinase. These carbohydrases have widespread application in the poultry industry but are used less commonly in feeds for swine.

The effect of carbohydrase supplementation on the performance of pigs is inconsistent. There are reports of positive responses to carbohydrase supplementation $[77,78]$, whereas others have reported no improvement in weight gain in response to enzymes [79-81]. Where positive effects on performance are observed, they are commonly associated with increases in nutrient digestibility likely as a result of increased accessibility of endogenous enzymes to nutrients as a result of inhibition of the "cage effect" as well as hydrolysis or partial hydrolysis of the non-starch polysaccharide. There also seems to be an influence on th e composition of the microflora in the digestive tract [76]. Hydrolysis of nonstarch polysaccharides results in increased sugar release in the large and small intestine and thereby stimulates the growth of lactobacilli which produce lactic acid. Increased proportions of lactic acid promote gut health by suppressing the growth of coliforms such as pathogenic E. coli.

Based on a review of the literature, it is clear that the response of pigs to supplementation with carbohydrases is less consistent than has been observed with poultry. The question is why? What differences are there in the physiology of the pig and the chicken that might account for the differences in the magnitude of the results obtained. One clear difference is the $\mathrm{pH}$ in the gut. In the pig, the duration that feed is exposed to a low $\mathrm{pH}$ is significantly longer than in the chicken [82]. Therefore,

Table 11 Comparison of the effects of a $\beta$-mannase produced using normal fermentation technology with that of a recombinant $\beta$-mannase on the performance of growing-finishing pigs

\begin{tabular}{|c|c|c|c|}
\hline Items & Control & $\beta$-mannase & $\%$ Improvement \\
\hline \multicolumn{4}{|c|}{ Traditional fermentation $^{1}$} \\
\hline Weight gain, g/d & 0.84 & 0.87 & 3.4 \\
\hline Feed intake, g/d & 2.50 & 2.48 & - \\
\hline Feed efficiency & 0.337 & 0.351 & 3.9 \\
\hline \multicolumn{4}{|c|}{ Recombinant technology ${ }^{2}$} \\
\hline Weight gain, g/d & 0.66 & 0.79 & 16.4 \\
\hline Feed intake, g/d & 1.66 & 1.61 & 3.0 \\
\hline Feed efficiency & 0.404 & 0.491 & 17.7 \\
\hline
\end{tabular}

${ }^{1}$ Pettey et al. [87].

${ }^{2}$ Lv et al. [85]. 
it is possible that exposure to the low $\mathrm{pH}$ in the stomach of the pig is either partially or totally denaturing the enzyme accounting for the lower magnitude of responses obtained when carbohydrases are fed to pigs compared with poultry.

Many of the enzyme preparations used in the past were unsuitable for use in the harsh environment of the pig's gastrointestinal tract. The $\mathrm{pH}$ in the stomach of the pig is usually between 2 and 3.5 and substantial reductions in $\beta$-glucanase [82] and xylanase [83] activity were reported when ten commercially available enzyme products were exposed in vitro to a $\mathrm{pH}$ of 2.5 or 3.5 for $30 \mathrm{~min}$.

The application of genetic engineering in the process of enzyme production allows the development of enzymes targeted for specific purposes [84-86]. Recently, several carbohydrases have been developed by molecular directed evolution which have considerable potential for animal feed application [84-86]. Enzymes have been developed which are active over a broad $\mathrm{pH}$ range, exhibit thermostability, are resistant to pepsin and trypsin, and viable under simulated gastric conditions.

Inclusion of a recombinant $\beta$-mannanase in corn soybean meal diets fed to growing pigs increased weight gain by $16.1 \%$ and feed efficiency by $17.7 \%$ compared with an unsupplemented diet (Table 11). The magnitude of the improvement was notably greater than previous experiments using $\beta$-mannanase produced by traditional fermentation techniques. For example, Pettey et al. [87] reported that weight gain was only increased $3.4 \%$ and feed efficiency $3.9 \%$ in their experiment in which growing-finishing pigs were fed diets supplemented with $\beta$-mannanase.

Enzymes added to feed are broken down in the digestive tract in the same way as other proteins [74]. Therefore, there are not any issues with residues and it is not necessary to observe any withdrawal periods before animals fed enzymes can be slaughtered [74]. For this reason, the amount of enzyme required is very small compared with the amount of substrate and therefore only small quantities are needed when using enzymes in ration formulation.

\section{Miscellaneous compounds}

Many additional compounds have been tested for their potential to replace antibiotics as growth promoters for use in swine production. They are too numerous to be able to go into much detail regarding their effectiveness. Some of the more promising include spray-dried porcine plasma [88,89], yeast culture [90-92], bacteriophages [93], lysozyme [94], bovine colostrum [95], lactoferrin [96-98], conjugated fatty acids $[99,100]$, chito-oligosaccarides $[101,102]$ and seaweed extract [103].

\section{Conclusions}

Clearly, a long and growing list of compounds exist which have been tested for their ability to replace antibiotics as feed additives to maintain swine health and performance. Unfortunately, the vast majority of these compounds produce inconsistent results and rarely equal antibiotics in their effectiveness. Therefore, it would appear that research is still needed in this area and that the perfect alternative does not exist as yet.

\section{Competing interests}

The author declares they have no competing interests.

Received: 3 July 2013 Accepted: 12 September 2013

Published: 14 September 2013

\section{References}

1. Cromwell GL: Why and how antibiotics are used in swine production. Anim Biotechnol 2002, 13:7-27.

2. Vondruskova H, Slamova R, Trckova M, Zraly Z, Pavli I: Alternatives to antibiotic growth promotors in prevention of diarrhea in weaned piglets: a review. Vet Med 2010, 55:199-224.

3. Van der Fels-Klerx HJ, Puister-Jansen LF, Van Asselt ED, Burgers SL: Farm factors associated with the use of antibiotics in pig production. $J$ Anim Sci 2011, 89:1922-1929.

4. Jacela JY, DeRouchey JM, Tokach MD, Goodband RD, Nelssen JL, Renter DG, Dritz SS: Feed additives for swine: fact sheets-prebiotics and probiotics, and phytogenics. J Swine Health Prod 2010, 18:132-136.

5. Simon O: An interdisciplinary study on the mode of action of probiotics in pigs. $J$ Anim Feed Sci 2010, 19:230-243.

6. Cho JH, Zhao PY, Kim IH: Probiotics as a dietary additive for pigs: a review. J Anim Vet Adv 2011, 10:2127-2134.

7. Halas V, Nochta I: Mannan oligosaccharides in nursery pig nutrition and their potential mode of action. Animals 2012, 2:261-274

8. Thacker PA: Recent advances in the use of enzymes with special reference to $\beta$-glucanases and pentosanases in swine rations. Asian-Aust J Anim Sci 2000, 13:376-385 (Special Issue).

9. Jacela JY, DeRouchey JM, Tokach MD, Goodband RD, Nelssen JL, Renter DG, Dritz SS: Feed additives for swine: fact sheets-carcass modifers, carbohydrate-degrading enzymes and proteases, and anthelmintics. J Swine Health Prod 2009, 17:325-332.

10. Adeola O, Cowieson AJ: Opportunities and challenges in using exogenous enzymes to improve nonruminant animal production. J Anim Sci 2011, 89:3189-3218.

11. Jacela JY, DeRouchey JM, Tokach MD, Goodband RD, Nelssen JL, Renter DG, Dritz SS: Feed additives for swine: fact sheets-acidifiers and antibiotics. J Swine Health Prod 2009, 17:270-275.

12. Kil DY, Kwon WB, Kim BG: Dietary acidifiers in weanling pig diets: a review. Revista Colombian de Diencias Pecuarias 2011, 24:1-22

13. Suruanarayana MV, Suresh J, Rajasekhar MV: Organic acids in swine feeding: a review. Agric Sci Res J 2012, 2:523-533.

14. Papatsiros VG, Billinis C: The prophylactic use of acidifiers as antibacterial agents in swine. In Antimicrobial agents. Edited by Bobbarala V; 2012:295310. InTech, DOl:10.5772/32278. Available from: http://www.intechopen. com/books/antimicrobial-agents/the-prophylactic-use-of-acidifiers-as-anti bacterial-agents-in-swine. ISBN 978-953-51-0723-1.

15. Windisch W, Schedle K, Plitzner C, Kroismayr A: Use of phytogenic products as feed additives for swine and poultry. J Anim Sci 2008, 86(E. Suppl):E140-E148.

16. Liu HW, Tong JM, Zhou DW: Utilization of Chinese herbal feed additives in animal production. Agric Sci China 2011, 10:1262-1272.

17. Pettigrew JE: Reduced use of antibiotic growth promoters in diets fed to weanling pigs: dietary tools, part 1. Anim Biotechnol 2006, 17:207-215.

18. Jacela JY, DeRouchey JM, Tokach MD, Goodband RD, Nelssen JL, Renter DG, Dritz SS: Feed additives for swine: fact sheets-high dietary levels of copper and zinc for young pigs, and phytase. J Swine Health Prod 2010, 18:87-91. 
19. Li YM, Xiang Q, Zhang QH, Huang YD, Su ZJ: Overview on the recent study of antimicrobial peptides: origins, functions, relative mechanisms and application. Peptides 2012, 37:207-215.

20. Koczulla AR, Bals R: Antimicrobial peptides: current status and therapeutic potential. Drugs 2003, 63:389-406.

21. Wu SD, Zhang FR, Huang ZM, Liu H, Xie CY, Zhang J, Thacker PA, Qiao S: Effect of the antibacterial peptide cecropin $A D$ on performance and intestinal health in weaned piglets challenged with Escherichia coli. Peptides 2012, 35:225-230.

22. Yusuf MA, Hamid TH: Lactic acid bacteria: bacteriocin producer: a mini review. IOSR J Pharm 2013, 3:44-50.

23. Stahl CH, Callaway TR, Lincoln LM, Lonergan SM, Genovese KJ: Inhibitory activities of colicins against Esherichia coli strains responsible for postweaning diarrhea and edema disease in swine. Antimicrob Agents Chemother 2004, 48:3119-3121.

24. Cutler SA, Lonergan SM, Cornick N, Johnson AK, Stahl CH: Dietary inclusion of colicin E1 is effective in preventing postweaning diarrhea caused by F18-positive Esherichia coli in pigs. Antimicrob Agents Chemother 2007, 51:3830-3835

25. Yoon JH, Ingale SL, Kim JS, Kim KH, Lohakare J, Park YK, Park JC, Kwon LK, Chae BJ: Effects of dietary supplementation with antimicrobial peptideP5 on growth performance, apparent total tract digestibility, faecal and intestinal microflora and intestinal morphology of weanling pigs. J Sci Food Agric 2013, 93:587-592.

26. Yoon JH, Ingale SL, Kim JS, Kim KH, Lee SH, Park YK, Kwon IK, Chae BJ: Effects of dietary supplementation of antimicrobial peptide-A3 on growth performance, nutrient digestibility, intestinal and fecal microflora and intestinal morphology in weanling pigs. Anim Feed Sci Technol 2012, 177:98-107

27. Wang JH, Wu CC, Feng J: Effect of dietary antibacterial peptide and zincmethionine on performance and serum biochemical parameters in piglets. Czech J Anim Sci 2011, 56:30-36.

28. Schell TC, Lindemann MD, Kornegay ET, Blodgett DJ: Effects of feeding aflatoxin-contained diets with and without clay to weanling and growing pigs on performance, liver function and mineral metabolism. J Anim Sci 1993, 71:1209-1218.

29. Schell TC, Lindemann MD, Kornegay ET, Blodgett DJ: Effects of different types of clay for reducing the detrimental effects of aflatoxin-contained diets on performance and serum profiles of weanling pigs. J Anim Sci 1993, 71:1226-1231.

30. Trckova M, Vondruskova H, Zraly Z, Alexa P, Kummer V, Maskova J, Mrlik V, Krizova K, Slana I, Leva L, Pavlik I: The effect of kaolin feeding on efficiency, health status and course of diarrheoal infections caused by enterotoxigenic Esherichia coli strains in weaned piglets. Vet Med 2009 $54: 47-63$

31. Song M, Liu Y, Soares JA, Che TM, Osuna O, Maddox CW, Pettigrew JE: Dietary clays alleviate diarrhea of weaned pigs. J Anim Sci 2012, 90:345-360.

32. Thacker PA: Performance of growing-finishing pigs fed diets containing graded levels of Biotite, and alumninosilicate clay. Asian-Aust J Anim Sci 2003, 16:1666-1672.

33. Chen YJ, Kwon OS, Min BJ, Son KS, Cho JH, Hong JW, Kim $H_{\text {: }}$ : The effects of dietary Biotite $\mathrm{V}$ supplementation as an alternative substance to antibiotics in growing pigs. Asian-Aust J Anim Sci 2005, 18:1642-1645

34. Prvulovic D, Jovanovic-Galovic A, Stanic B, Popovic M, Grubor-Lajsic G: Effects of a clinoptilolite supplement in pig diets on performance and serum parameters. Czech J Anim Sci 2007, 52:159-164.

35. Yan L, Hong SM, Kim IH: Effect of bacteriophage supplementation on the growth performance, nutrient digestibility, blood characteristics, and fecal microbial shedding in growing pigs. Asian-Aust J Anim Sci 2012, $25: 1451-1456$

36. Xu Y, Li X, Jin L, Zhen Y, Lu Y, Li S, You J, Wang L: Application of chicken egg yolk immunoglobulins in the control of terrestrial and aquatic animal diseases: a review. Biotechnol Adv 2011, 29:860-868.

37. Chalghoumi R, Beckers $Y$, Portetelle D, Thewis A: Hen egg yolk antibodies $(\lg Y)$ production and use for passive immunization against bacterial enteric infections in chicken: a review. Biotechnol Agron Soc Environ 2009, 13:295-308

38. Kovacs-Nolan J, Mine Y: Egg yolk antibodies for passive immunity. Annu Rev Food Sci Technol 2012, 3:163-182.

39. Marquardt RR, Jin LZ, Kim JW, Fang L, Frohlich AA, Baidoo SK: Passive protective effect of egg-yolk antibodies against enterotoxigenic
Esherichia coli K88+ infection in neonatal and early-weaned piglets. FEMS Immunol Med Microbiol 1999, 23:283-288.

40. Owusu-Asiedu A, Nyachoti CM, Baidoo SK, Marquardt RR, Yang X: Response of early-weaned pigs to an enterotoxigenic Esherichia coli (K88) challenge when fed diets containing spray-dried porcine plasma or pea protein isolate plus egg yolk antibody. J Anim Sci 2003, 81:1781-1789.

41. Owusu-Asiedu A, Nyachoti CM, Marquardt RR: Response of early-weaned pigs to an enterotoxigenic Esherichia coli (K88) challenge when fed diets containing spray-dried porcine plasma or pea protein isolate plus egg yolk antibody, zinc oxide, fumaric acid or antibiotic. J Anim Sci 2003, 81:1790-1798.

42. Hong JW, Kwon OS, Min BJ, Lee WB, Shon KS, Kim IH, Kim JW: Evaluation effects of spray-dried egg protein containing specific egg yolk antibodies as a substitute for spray-dried plasma protein or antibiotics in weaned pigs. Asian-Aust J Anim Sci 2004, 17:1139-1144.

43. Zhang ZF, Kim IH: Effects of egg yolk immunoglobulin on growth performance, diarrhea score, diarrhea incidence and serum antibody titer in pre-and post-weaned pigs. Wayamba J Anim Sci 2013, 578X:590-597.

44. Chernysheva LV, Friendship RM, Dewey CE, Gyles CL: The effect of dietary chicken egg-yolk antibodies on the clinical response in weaned pigs challenged with a K88+ Esherichia coli isolate. J Swine Health Prod 2003, 12:119-122.

45. Kovacs-Nolan J, Mine Y: Microencapsulation for the gastric passage and controlled intestinal release of immunoglobulin Y.J Immunol Methods 2005, 296:199-209.

46. Li XY, Jin LJ, Uzonna JE, Li SY, Liu JJ, Li HQ, Lu YN, Zhen YH, Xu YP. Chitosan-alginate microcapsules for oral delivery of egg yolk immunoglobulin ( $\lg Y$ ): in vivo evaluatin in a pig model of enteric colibacillosis. Vet Immunol Immunopathol 2009, 129:132-136.

47. Li XY, Jin LJ, McAllister TA, Stanford $K, X u J Y$, Lu YN, Zhen $Y H$, Sun $Y X, X u$ $Y P$ : Chitosan-alginate microcapsules for oral delivery of egg yolk immunoglobulin (IgY). J Agric Food Chem 2007, 55:2911-2917.

48. Stein HH, Kil DY: Reduced use of antibiotic growth promoters in diets fed to weanling pigs: dietary tools, Part 2. Anim Biotechnol 2006, 17:217-231.

49. Gatnau R: Use of plant extracts in swine; 2009. Available at http://www. pig333.com/nutrition/use-of-plant-extracts-in-swine_957/.

50. Michiels J, Missotten JA, Fremaut D, De Smet S, Dierick NA: In vitro characterization of the antimicrobial activity of selected essential oil components and binary combinations against the pig gut flora. Anim Feed Sci Technol 2009, 151:111-127.

51. Brenes A, Roura E: Essential oils in poultry nutrition: main effects and modes of action. Anim Feed Sci Technol 2010, 158:1-14.

52. Ragland D, Stevenson D, Hill MA: Oregano oil and multi-component carbohydrases as alternatives to antimicrobials in nursery diets. Swine Health Prod 2008, 16:238-243.

53. Cho JH, Chen YJ, Min BJ, Kim HJ, Kwon OS, Shon KS, Kim IH, Kim SJ, Asamer A: Effects of essential oils supplementation on growth performance, IgG concentration and fecal noxious gas concentration of weaned pigs. Asian-Aust J Anim Sci 2006, 19:80-85.

54. Maenner K, Vahjen W, Simon O: Studies on the effects of essential-oil based feed additives on performance, ileal nutrient digestibility, and selected bacterial groups in the gastrointestinal tract of piglets. J Anim Sci 2011, 89:2106-2112.

55. Li PF, Piao XS, Ru YJ, Han X, Xue LF, Zhang HY: Effects of adding essential oil to the diet of weaned pigs on performance, nutrient utilization, immune response and intestinal health. Asian-Aust J Anim Sci 2012, 25:1617-1626.

56. Ahmed ST, Hossain ME, Kim GM, Hwang JA, Ji H, Yang CJ: Effect of resveratrol and essential oils on growth performance, immunity, digestibility and fecal microbial shedding in challenged piglets. Asian-Aust J Anim Sci 2013, 26:683-690.

57. Huang Y, Yoo JS, Kim HJ, Wang Y, Chen YJ, Cho JH, Kim IH: Effects of dietary supplementation with blended essential oils on growth performance, nutrient digestibility, blood profiles and fecal characteristics in weanling pigs. Asian-Aust J Anim Sci 2010, 23:607-613.

58. Salari MH, Amine G, Shirazi MH, Hafezi R, Mohammadypour M: Antibacterial effects of Eucalyptus globulus leaf extract on pathogenic bacteria isolated from specimens of patients with respiratory tract disorders. Clin Microbiol Infect 2006, 12:194-196.

59. Serafino A, Vallebona PS, Andreola F, Zonfrillo M, Mercuri L, Federici M, Rasi G, Garaci E, Pierimarchi P: Stimulatory effect of Eucalyptus essential oil on innate cell-mediated immune response. BMC Immunol 2008, 9:17. 
60. Abd El-Motaal AM, Ahmed AMH, Bahakaim ASA, Fathi MM: Productive performance and immunocompetence of commercial laying hens given diets supplemented with Eucalyptus. Int J Poult Sci 2008, 7:445-449.

61. Dierick NA, Decuypere JA, Molly K, Van Beek E, Vanderbecke E: The combined use of triacylglycerols containing medium-chain fatty acids and exogenous lipolytic enzymes as an alternative for nutritional antibiotics in piglet nutrition: I: in vitro screening of the release of MCFAs from selected fat sources by selected exogenous lipolytic enzymes under simulated pig gastric conditions and their effects on the gut flora of piglets. Livest Prod Sci 2002, 75:129-142.

62. Dierick NA, Decuypere JA, Molly K, Van Beek E, Vanderbecke E: The combined use of triacylglycerols containing medium-chain fatty acids and exogenous lipolytic enzymes as an alternative for nutritional antibiotics in piglet nutrition: II: in vivo release of MCFAs in gastric cannulated and slaughtered piglets by endogenous and exogenous lipases: effects on the luminal gut flora and growth performance. Livest Prod Sci 2002, 76:1-16.

63. Hong SM, Hwang $\mathrm{JH}$, Kim $\mathrm{H}$ : Effect of medium-chain triglyceride (MCT) on growth performance, nutrient digestibility, blood characteristics in weanling pigs. Asian-Aust J Anim Sci 2012, 25:1003-1008.

64. Rossi R, Pastorelli G, Cannata S, Corino C: Recent advances in the use of fatty acids as supplements in pig diets: a review. Anim Feed Sci Technol 2010, 162:1-11.

65. Han YK, Hwang UH, Thacker PA: Use of a micro-encapsulated medium chain fatty acid product as an alternative to zinc oxide and antibiotics for weaned pigs. J Swine Health Prod 2011, 19:34-43.

66. Redling K: Rare earth elements in agriculture with emphasis on animal husbandry. Muenchen: Diss Ludwig-Maximilians-Universitaet; 2006:325.

67. Zhu X, Li D, Yang W, Xiao C, Chen H: Effects of rare earth elements on the growth and nitrogen balance of piglets. Feed Industry 1994, 15:23-25.

68. He R, Xia Z: Effects of rare earth elements on growing and fattening of pigs. Guangxi Agric Sci 1998, 5:243-245.

69. Rambeck WA, Wehr U: Rare earth elements as alternative growth promoters in pig production. Arch Tierernahr 2000, 53:323-334.

70. He ML, Rambeck WA: Rare earth elements: a new generation of growth promoters for pigs. Arch Anim Nutr 2000, 53:323-334.

71. He ML, Ranz D, Rambeck WA: Study on the performance enhancing effect of rare earth elements in growing and finishing pigs. J Anim Physiol Anim Nutr 2001, 85:263-270

72. Kraatz M, Taras D, Manner K, Simon O: Weaning pig performance and faecal microbiota with and without in-feed addition of rare earth elements. J Anim Physiol Anim Nutr 2006, 90:361-368.

73. Han YK, Thacker PA: Effect of antibiotics, zinc oxide and rare earth mineral yeast on performance, nutrient digestibility and blood parameters in weaned pigs. Asian-Aust J Anim Sci 2010, 23:1057-1065.

74. Buhler M, Limper J, Muller A, Schwarz G, Simon O, Sommer M, Spring W: Enzymes in animal nutrition. German Feed Additives Association Fact Sheet; 2013. Available at http://www.awt-feedadditives.de/Publikationen/Enzymbro-engl.pdf.

75. Choct M: Feed non-starch polysaccharides: chemical structures and nutritional significance. Singapore: Proceedings of the Feed Ingredients Asia 97 Conference; 1997.

76. Metzler B, Bauer B, Mosenthin R: Microflora management in the gastrointestinal tract of piglets. Asian-Aust J Anim Sci 2005, 18:1353-1362.

77. Kiarie E, Nyachoti CM, Slominski BA, Blank G: Growth performance, gastrointestinal microbial activity, and nutrient digestibility in earlyweaned pigs fed diets containing flaxseed and carbohydrase enzyme. J Anim Sci 2007, 85:2982-2993.

78. Emiola IA, Opapeju FO, Slominski BA, Nyachoti CM: Growth performance and nutrient digestibility in swine fed wheat distillers dried grains with solubles-based diets supplemented with a multi-carbohydrase enzyme. J Anim Sci 2009, 87:2315-2322.

79. Thacker PA: Effect of enzyme supplementation on the performance of growing-finishing pigs fed barley based diets supplemented with soybean meal or canola meal. Asian-Aust J Anim Sci 2001, 14:1008-1013.

80. Olukosi OA, Sands JS, Adeola O: Supplementation of carbohydrases or phytase individually or in combination to diets for weanling and growing-finishing pigs. J Anim Sci 2007, 85:1702-1711.

81. Jones CK, Bergstrom JR, Tokach MD, DeRouchey JM, Goodband RD, Nelssen $J$, Dritz SS: Efficacy of commercial enzymes in diets containing various concentrations and sources of dried distillers grains with solubles for nursery pigs. J Anim Sci 2010, 88:2084-2091.
82. Baas TC, Thacker PA: Impact of gastric $\mathrm{pH}$ on dietary enzyme activity and survivability in swine fed $\beta$-glucanase supplemented diets. Can J Anim Sci 1996, 76:245-252.

83. Thacker PA, Baas TC: Effect of gastric pH on the activity of exogenous pentosanase and the effect of pentosanase supplementation of the diet on the performance of growing-finishing pigs. Anim Feed Sci Technol 1996, 63:187-200.

84. He J, Yin J, Wang L, Yu B, Chen D: Functional characterization of a recombinant xylanase from Pichia pastoris and effect of the enzyme on nutrient digestibility in weaned pigs. Brit J Nutr 2010, 103:1507-1513.

85. LV JN, Chen YQ, Guo XJ, Piao XS, Cao YH, Dong B: Effects of supplementation of $\beta$-mannanase in corn-soybean meal diets on performance and nutrient digestibility in growing pigs. Asian-Aust J Anim Sci 2013, 26:579-587.

86. Cai $H$, Shi $P$, Luo $H$, Bai $Y$, Huang $H$, Yang $P$, Yao B: Acidic $\beta$-mannanase from penicillium pinophilum $\mathrm{C}$ : cloning, characterization and assessment of its potential for animal feed application. J Biosci Bioeng 2011, 112:551-557

87. Pettey LA, Carter SD, Senne BW, Shriver JA: Effect of beta-mannanase adding to corn-soybean meal diets on growth performance, carcass traits and apparent nutrient digestibility in growing-finishing pigs. J Anim Sci 2002, 80:1012-1019.

88. Van Dijk AJ, Everts H, Nabuurs MJA, Margry RJ, Beynen AC: Growth performance of weanling pigs fed spray-dried animal plasma: a review. Livest Prod Sci 2001, 68:263-274.

89. Torrallardona D: Spray dried animal plasma as an alternative to antibiotics in weanling pigs: a review. Asian-Aust J Anim Sci 2010, 23:131-148.

90. Bontempo V, Di Giancamillo A, Savoini G, Dell'Orto V, Domeneghini C: Live yeast supplementation acts upon intestinal morpho-functional aspects and growth in weanling piglets. Anim Feed Sci Technol 2006, 129:224-236.

91. Li JY, Li DF, Gong LM, Ma YX, He YH, Zhai HX: Effects of live yeast on the performance, nutrient digestibility, gastrointestinal microbiota and concentration of volatile fatty acids in weanling pigs. Arch Anim Nutr 2006, 60:277-288.

92. Shen YB, Piao XS, Kim SW, Wang L, Liu P, Yoon I, Zhen YG: Effects of yeast culture supplementation on growth performance, intestinal health, and immune response of nursery pigs. J Anim Sci 2009, 87:2614-2624.

93. Yan L, Han DL, Meng QW, Lee JH, Park CJ, Kim IH: Effects of anion supplementation on growth performance, nutrient digestibility, meat quality and fecal noxious gas content in growing-finishing pigs. Asian-Aust J Anim Sci 2010, 23:1073-1079.

94. Nyachoti CM, Kiarie E, Bhandari SK, Zhang G, Krause DO: Weaned pig responses to Esherichia coli $\mathrm{K} 88$ oral challenge when receiving a lysozyme supplement. J Anim Sci 2012, 90:252-260.

95. Huguet A, Le Dividich J, Le Huerou-Luron I: Improvement of growth performance and sanitary status of weaned piglets fed a bovine colostrum-supplemented diet. J Anim Sci 2012, 90:1513-1520.

96. Wang $Y$, Shan $T, X u Z$, Liu J, Feng J: Effect of lactoferrin on the growth performance, intestinal morphology and expression of PR-39 and protegrin-1 genes in weaned piglets. J Anim Sci 2006, 84:2636-2641.

97. Shan T, Wang Y, Liu J, Xu Z: Effect of dietary lactoferrin on the immune functions and serum iron level of weanling piglets. J Anim Sci 2007, 85:2140-2146

98. Garcia-Montoya IA, Cendon TS, Arevalo-Gallegos S, Rascon-Cruz Q: Lactoferrin a multiple bioactive protein: an overview. Biochim Biophys Acta 1820, 2012:226-236

99. Lai CH, Yin JD, Li DF, Zhao LD, Qiao SY, Xing JJ: Conjugated linoleic acid attenuates the production and gene expression of pro-inflammatory cytokines in weaned pigs challenged with lipopolysaccharide. J Nutr 2005, 135:239-244.

100. Lai CH, Yin JD, Li DF, Zhao LD, Chen XJ: Effects of dietary conjugated linoleic acid supplementation on the performance and immunological responses of weaned pigs after an escherichia coli lipopolysaccharide challenge. J Anim Vet Adv 2005, 2:299-305.

101. Liu P, Piao XS, Thacker PA, Zheng ZK, Wong D, Kim SW: Chito-oligosaccharide reduces diarrhea incidence and attenuates the immune response of weanling pigs challenged with E. coli K88. J Anim Sci 2010, 88:3871-3879.

102. Liu P, Piao XS, Kim SW, Li XJ, Wang L, Shen YB, Lee HS, Li SY: Effects of chito-oligosaccharide supplementation on the growth performance, nutrient digestibility, intestinal morphology, and fecal shedding of 
Escherichia coli and Lactobacilli in weaning pigs. J Anim Sci 2008, 86:2609-2618.

103. O'Doherty JV, Dillon S, Figat S, Callan JJ, Sweeney T: The effects of lactose inclusion and seaweed extract derived from Laminaria spp. on performance, digestibility of diet components and microbial populations in newly weaned pigs. Anim Feed Sci Technol 2010, 157:173-180.

doi:10.1186/2049-1891-4-35

Cite this article as: Thacker: Alternatives to antibiotics as growth promoters for use in swine production: a review. Journal of Animal Science and Biotechnology 2013 4:35.

\section{Submit your next manuscript to BioMed Central and take full advantage of:}

- Convenient online submission

- Thorough peer review

- No space constraints or color figure charges

- Immediate publication on acceptance

- Inclusion in PubMed, CAS, Scopus and Google Scholar

- Research which is freely available for redistribution 